\title{
Monika Gwoździk
}

\section{EVALUATION OF MICROSTRUCTURE OF STEEL FOR THE POWER INDUSTRY BY MEANS OF THE TRIAFOLE REPLICA METHOD}

\author{
OCENA MIKROSTRUKTURY STALI \\ DLA ENERGETYKI METODA REPLIK TRIAFOLOWYCH
}

\begin{abstract}
The paper presents microstructures of steel designated for the operation at elevated temperatures in the power industry. Materials were examined both in the initial state as well as after the operation. The microstructure was examined using triafol replicas to determine the degree of materials wearing out. The quality of the structure representation on triafol replicas was checked, comparing them with the images from microsections. Attempts were made to improve the structure image quality on replicas through application of various degrees of microsection etching, and observation of unshaded and shaded replicas.

The paper presents also most frequently encountered technological defects originating during replica preparation.
\end{abstract}

Key words: non-destructive testing, triafole replica, 10CrMo9-10 steel, power industry

\section{Streszczenie}

W pracy przedstawiono zagadnienie mikrostruktury stali przeznaczonych dla energetyki do pracy w podwyższonej temperaturze. Badano materiał zarówno w stanie wyjściowym, jak i po eksploatacji. Badania mikrostruktury wykonano metodą replik triafolowych w celu określenia stopnia wyeksploatowania materiału. Sprawdzono jakość odwzorowania struktury na replikach triafolowych, porównując je z obrazami ze zgładów metalograficznych. Podjęto próby poprawy jakości obrazu struktury na replikach przez stosowanie różnego stopnia wytrawienia zgładów oraz obserwacje replik niecieniowanych i cieniowanych.

W artykule omówiono także najczęściej spotykane wady technologiczne powstające podczas wykonywania replik.

Słowa kluczowe: badania nieniszczące, repliki triafolowe, stal 10CrMo9-10, energetyka

Monika Gwoździk, PhD: Częstochowa University of Technology, Institute of Materials Engineering,

Częstochowa, Poland; e-mail: gwozdzik@wip.pcz.pl 


\section{Introduction}

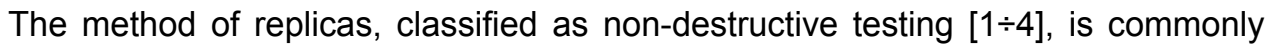
used to evaluate components operating for a long term at elevated temperatures. The advantage of this method consists in performing examinations directly on the object. Replicas are prepared mainly to reveal defects originating during component operations, including primarily cracks originating during operation. Newman et al. [4] using the method of replicas determined the nature of cracks originating in a space shuttle engine.

In the case of steels and alloys operating at elevated temperatures the tests on replicas are carried out to determine structural changes occurring in those steels during thousands of hours at elevated temperatures. Changes in the structure result in decreasing mechanical properties and increasing brittleness. Apart from temperature, mechanical properties are also affected by the magnitude of stress and the time of load operation. A low plasticity and susceptibility to brittle cracking are the most frequent rea-

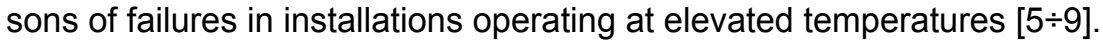

During the operation of power equipment alloying elements diffuse from ferrite to carbide phases, what results in a change of matrix and carbides chemical composition. Then carbides growth, spheroidisation and coagulation occur, resulting in the decomposition of the primary pearlite/bainite structure. At the same time there is a preferred carbide precipitation on grain boundaries, accompanied by depletion of boundary zones in carbides.

The nucleation of voids (pores) on weakened boundaries is the next stage. Creep pores usually nucleate at grain boundaries and at the boundary between the matrix and the carbide precipitates or non-metallic inclusions. In most cases voids nucleate in areas of components, where tensile stresses occur at an angle of $45^{\circ}$ or $90^{\circ}$. Then, as a result of diffusion and deformation mechanisms, voids (micropores) grow, creating the characteristic arrangements of chains along the grain boundaries. At a further stage microcracks originate as a result of chain linking. This is followed by microcrack joining, which result in the macrocracks origination and finally in the component's failure $[5,8 \div 10]$.

The study aimed at determination of replica method examinations usability for the evaluation of the degree of steel wearing out as well as at determination of the fidelity of structure replication by the triafol replicas.

\section{Material and methodology of tests}

Heat-treated (denoted as 1) and after operation (denoted as 2) 10CrMo9-10 steel was examined. The chemical composition of the studied materials was analysed using the emission spectroscopy method on a Spectro emission spark spectrometer. The chemical composition of the steels examined (Tab. 1) was consistent with standard EN 10028-2:2005 [11].

The heat treatment of steel taken from a new pipe consisted in water quenching from $960^{\circ} \mathrm{C}$. The austenitising time was equal to $1 \mathrm{~h}$. Then the material was tempered during $5 \mathrm{~h}$ at $700^{\circ} \mathrm{C}$ with air cooling.

The operated material originated from a steam superheater after $123,000 \mathrm{~h}$ of operation at a pressure of $14 \mathrm{MPa}$ and a temperature of $580^{\circ} \mathrm{C}$. 
Table 1. Chemical composition of steel selected for tests, wt.\%

\begin{tabular}{|c|c|c|c|c|c|c|c|c|c|}
\hline Acc. to & $\mathrm{C}$ & $\mathrm{Mn}$ & $\mathrm{Si}$ & $\mathrm{P}$ & $\mathrm{S}$ & $\mathrm{Cr}$ & $\mathrm{Mo}$ & $\mathrm{Ni}$ & $\mathrm{Cu}$ \\
\hline analysis (1) & 0.13 & 0.46 & 0.39 & 0.018 & 0.006 & 2.23 & 0.96 & 0.31 & 0.14 \\
\hline analysis (2) & 0.11 & 0.51 & 0.20 & 0.010 & 0.004 & 2.36 & 1.06 & 0.14 & 0.14 \\
\hline EN & $\begin{array}{c}0.08 \\
\div 0.14\end{array}$ & $\begin{array}{c}0.40 \\
\div 0.80\end{array}$ & $\begin{array}{c}\text { max. } \\
0.50\end{array}$ & $\begin{array}{c}\text { max. } \\
0.030\end{array}$ & $\begin{array}{c}\text { max. } \\
0.025\end{array}$ & $\begin{array}{c}2.00 \\
\div 2.50\end{array}$ & $\begin{array}{c}0.90 \\
\div 1.10\end{array}$ & - & $\begin{array}{c}\text { max. } \\
0.30\end{array}$ \\
\hline
\end{tabular}

Structural examinations were performed parallel on the nital (4\% nitric acid solution) etched microsections by the method of triafol replicas. Observations and microstructural analyses were carried out on a Carl Zeiss Jena Axiovert 25 optical microscope working with a Sony Mavica MVC-FD 87 digital camera.

Replicas were prepared from a triafol foil, from which triafol strips were cut out adjusting them to the specimen dimensions. Then a strip of triafol was immersed in methyl acetate for two seconds and then gravitationally (without pressure) put on the microsection and removed after drying.

During the examinations, attempts were made to improve the structure quality on replicas through:

- using various degrees of microsection etching, i.e. replicas reproduced from underetched, properly etched and overetched microsections were observed,

- observation of replicas unshaded and shaded with a marker.

To make results reliable, the same places on the microsections and corresponding replicas have been presented. Because the structure reproduced on a replica presents a negative of microsection surface image, pictures made from triafol replicas have been inverted for their easier comparison with images from the microsections.

\section{Results analysis}

The steel after quenching and tempering at $700^{\circ} \mathrm{C}$ had a structure of fine-grained martensite of grain size 8.0 $\div 7.0$ acc. to EN ISO 643:2005 [12] (Fig. 1).

a)

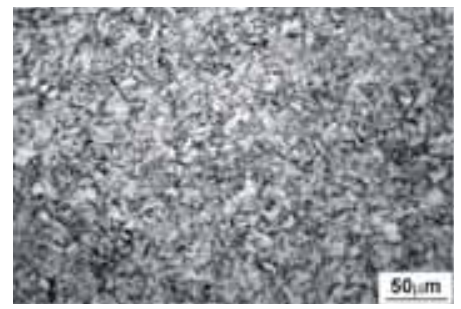

b)

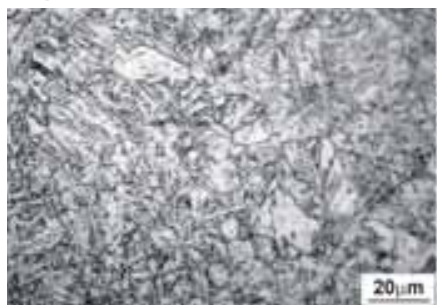

c)

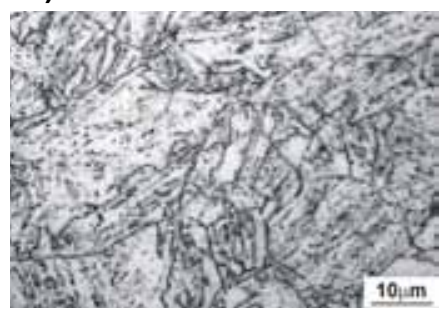

Fig. 1. The structure of 10CrMo9-10 steel: a) water-quenched, b) austenitised in $1 \mathrm{~h}, \mathrm{c}$ ) tempered in $5 \mathrm{~h}$ 
Proper microsection etching (30 s) is sufficient to make replicas from 10CrMo9-10 steel (Fig. 2). Examinations on an optical microscope of a triafol replica taken from the microsection of heat-treated 10CrMo9-10 steel have revealed, apart from the structure discussed above, also bright shining points. These points exist primarily in the areas, where carbides are present, hence on grain boundaries and in the tempered martensite. These are carbide precipitates torn out from the microsection.

A better image quality was obtained by shading the replica. Figure 3 presents the microstructure of the 10CrMo9-10 steel on a replica, which right-hand part was shaded with a marker. In the case of shading with a marker, the shading substance was put on the opposite side of the reproduction.

a)

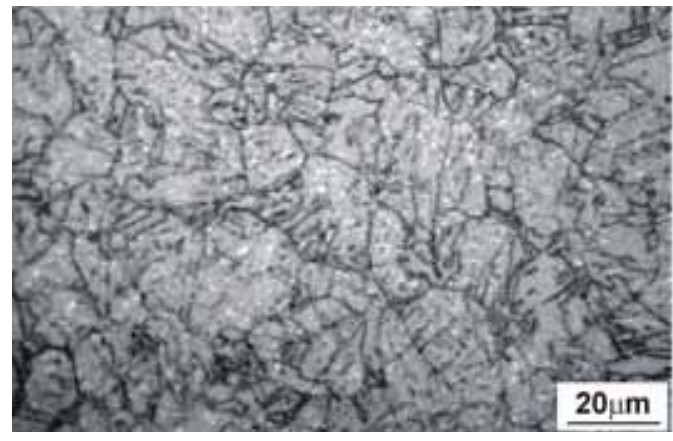

b)

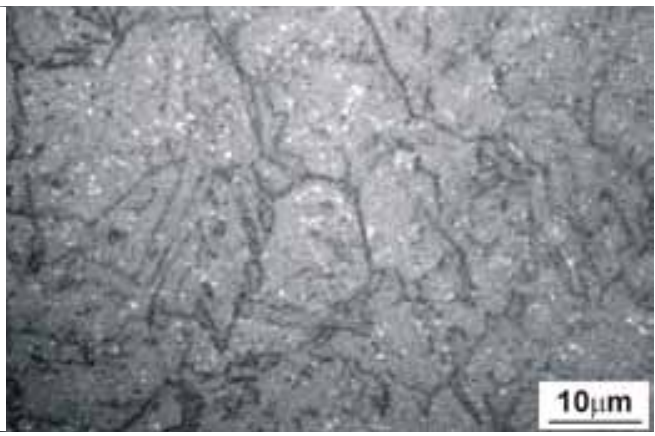

Fig. 2. The structure of: a) austenitised in $1 \mathrm{~h}, \mathrm{~b}$ ) tempered 10CrMo9-10 steel triafol replica

a)

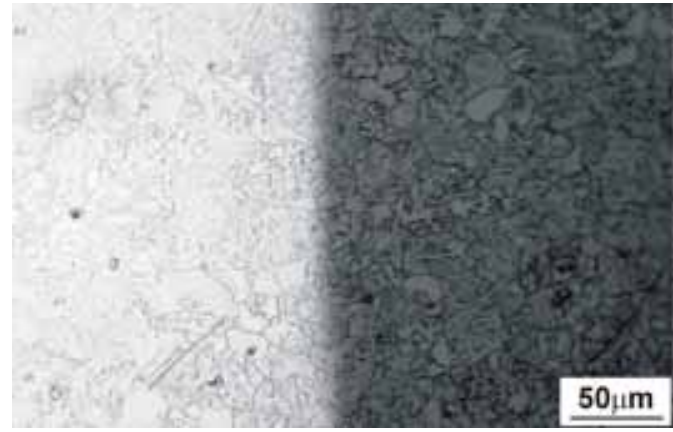

b)

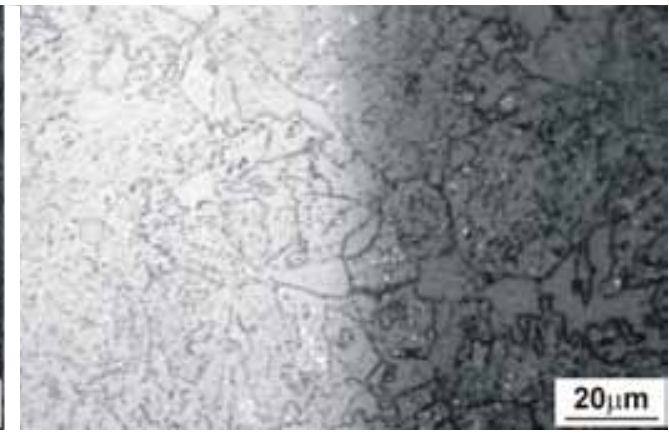

Fig. 3. Non-shaded (left-hand part) and shaded with a marked (right-hand part) replica, a) and b) using different magn.

Figure 3 shows the difference between the shaded and non-shaded replica; elements of the structure, where the shading has been applied, are much clearer. Such replica's quality is not worse, than that of replicas shaded with copper or carbon in the spraying devices.

10CrMo9-10 steel after the operation had a bainitic-ferritic structure (quasi-polygonal and polygonal ferrite) of bainite grain size $10.0 \div 7.0$, ferrite grain size $10.0 \div 7.5$ acc. to EN ISO 643:2005. Numerous creep micropores are visible in the structure (arrows show creep micropores, which are situated most often at the contact of two and three grains), indicating substantial degradation of the structure (Fig. 4). 
a)

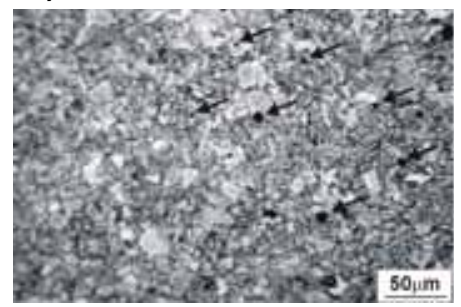

b)

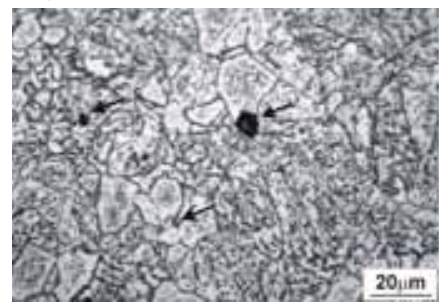

c)

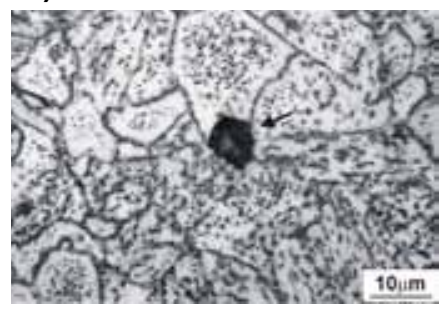

Fig. 4. The structure of the $10 \mathrm{CrMo9}-10$ steel, operated in $123,000 \mathrm{~h}$ at a pressure of $14 \mathrm{MPa}$ and a temperature of $580^{\circ} \mathrm{C}$, etched for the $30 \mathrm{~s}$. a $\div \mathrm{c}$ ) using different magn.

a)

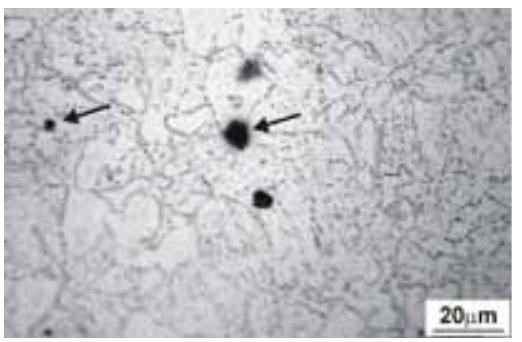

b)

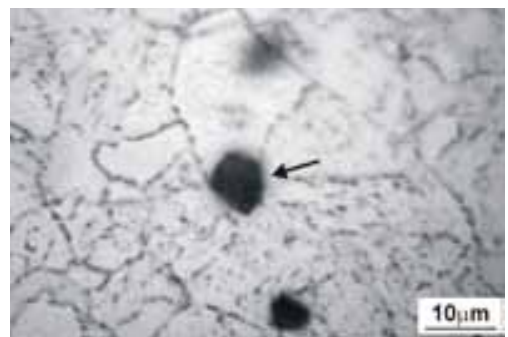

Fig. 5. The structure of the 10CrMo9-10 steel on a non-shaded triafol replica, microsection etched for $30 \mathrm{~s}, \mathrm{a}$ ) and b) using different magn.

The interpretation of replicas needs a lot of experience, because apart from the structure reproduction also defects originating e.g. from introducing a dust particle on the replica may occur, what is shown in Figure 5.

Additional elements are visible on the replica (most likely dust particles introduced), which look like creep pores, in particular at low magnifications. A previous observation of the microsection of the same area is shown (Fig. 4) that creep micropores occur in places marked with arrows. The shading of the same replica with a marker resulted in removing from the replica the impurities introduced onto it, only the actual pores remained (Fig. 6). Apart from a micropore, a hole after the fallen off particle, most likely a sulphide, is visible.

The quality of structure reproduction on replicas is also affected by the degree of replicas corrugation. Figure 7 shows a replica glued on a laboratory glass slide, what allowed increasing the replica's flatness substantially and due to that obtaining a clearer and sharper image. The same replica before gluing onto the glass is presented in Figure 6 .

a)

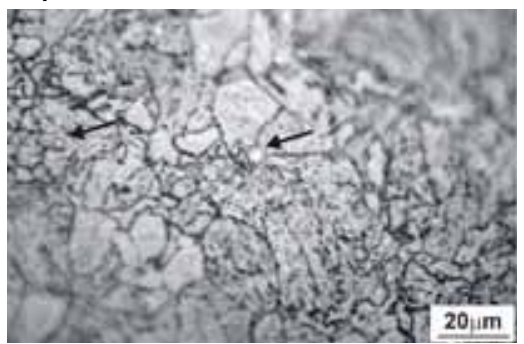

b)

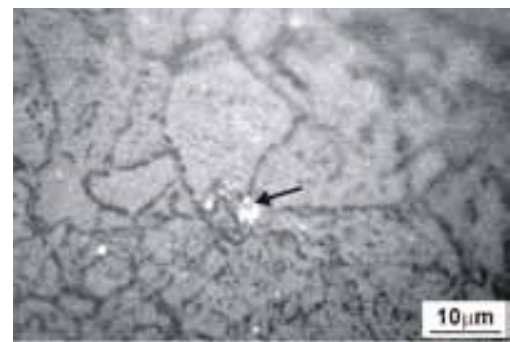

Fig. 6. The structure of the $10 \mathrm{CrMo9}-10$ steel on a triafol replica shaded with a marker, microsection etched for the $30 \mathrm{~s}, \mathrm{a}$ ) and b) using different magn. 
a)

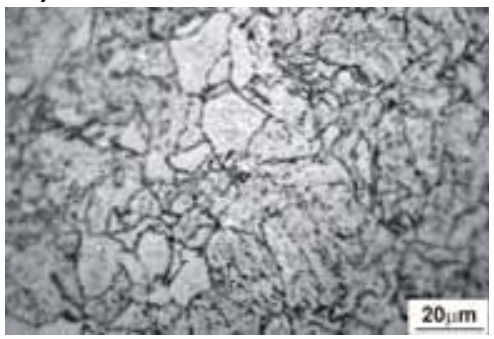

b)

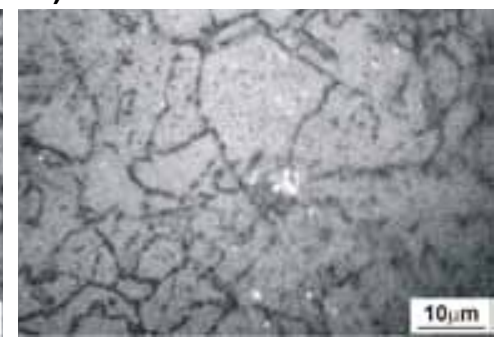

Fig. 7. The structure of the $10 \mathrm{CrMo9}-10$ steel on a triafol replica shaded with a marker, glued on a laboratory glass slide, microsection etched during the $30 \mathrm{~s}, \mathrm{a}$ ) and b) using different magn.

The quality of the image of the structure reproduced on the replica is affected by the intensity of the etching. Many years of practice have shown that microsections should be slightly overetched, while never underetched. Very poor reproduction of the structure and sometimes even its absence occurs for replicas made on underetched microsections A replica made on a microsection etched in such a way may result in an erroneous interpretation.

Instead, a slight overetching (microsection etched for the $60 \mathrm{~s}$ ) has a favourable effect, because the difference in height increases and thereby the image contrast improves. An example of overetched 10CrMo9-10 steel microstructure is presented in Figure 8.

An overetching ensures good reproduction of the structure and distinguishability of details, what is shown in Figure 9. Apart from creep pores, carbide precipitations at grain boundaries and boundary zones depletion in carbides are visible.

a)

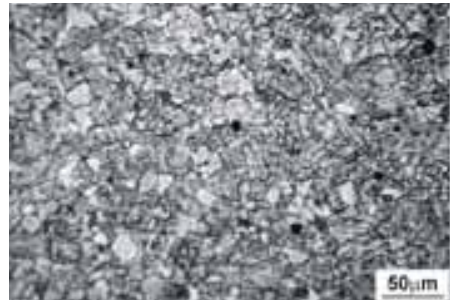

b)

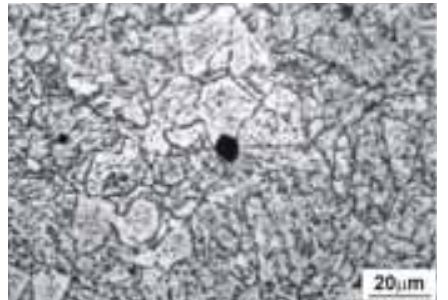

c)

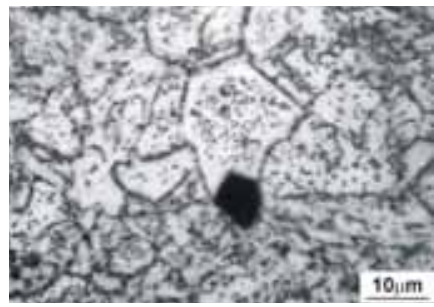

Fig. 8. The structure of the 10CrMo9-10 steel, operated during $123,000 \mathrm{~h}$ at a pressure of $14 \mathrm{MPa}$ and a temperature of $580^{\circ} \mathrm{C}$, etched for the $60 \mathrm{~s}, a \div \mathrm{c}$ ) using different magn.

a)

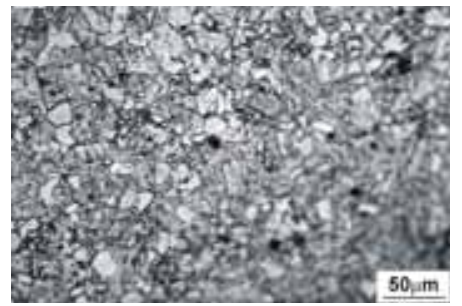

b)

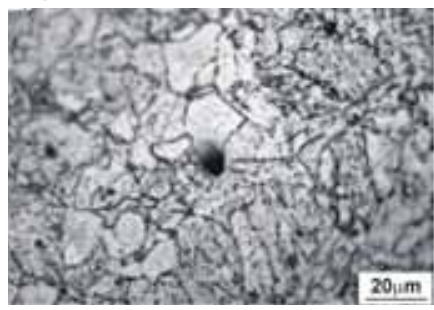

c)

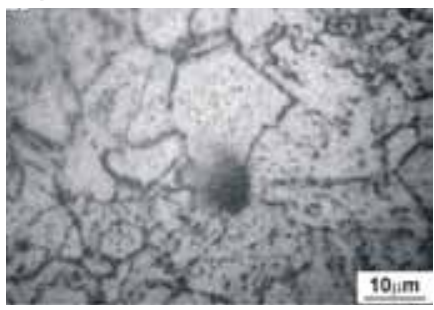

Fig. 9. The structure of the $10 \mathrm{CrMo}-10$ steel on a triafol replica shaded with a marker, microsection etched for the $60 \mathrm{~s}, \mathrm{a} \div \mathrm{c}$ ) using different magn. 
A number of technological defects may also originate during triafol replicas preparation. One of most frequent are defects in the form of large (1 to a few grains in size) brightly shining spots, usually spherical in shape (Fig. 10). These are air bubbles originating from the lack of microsection contact with the triafol foil.

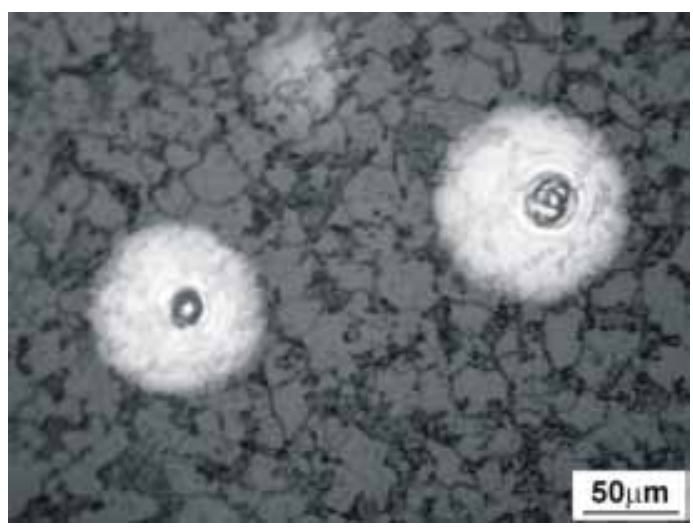

Fig. 10. Technological defects originating during triafol replica preparation

During many years of triafol replicas observation by the paper's author also other technological defects have been identified, including frequently occurring clusters of "pseudo inclusions", which may be wrongly interpreted as etched out areas originating around carbides or sulphides. "Pseudo inclusions" originate during the drying of triafol foil, previously immersed in methyl acetate. As a result of immersion in methyl acetate the triafol is partially dissolved, then during drying the dissolved particles redeposit on the triafol foil. To check, whether these are technological defects, a strip of triafol was immersed for two seconds in methyl acetate and after taking it from the reagent it was dried, without putting on a microsection. The foil prepared this way was then subject to observations on an optical microscope, what is shown in Figure 11. Numerous clusters of "pseudo inclusions" are visible. However, "pseudo inclusions" differ substantially from the etched out areas around the carbide or sulphide precipitates. Primarily they are different in shape, which in most cases is perfectly spherical, unusual for precipitates. It is easier to distinguish such defects from etched out areas, when they form clusters. The occurrence of single defects of this type (in particular, where they are very small in the size, what makes the interpretation difficult even at the high magnifications), and inaccurate reproductions of the structure may result in an erroneous interpretation of replicas.

a)

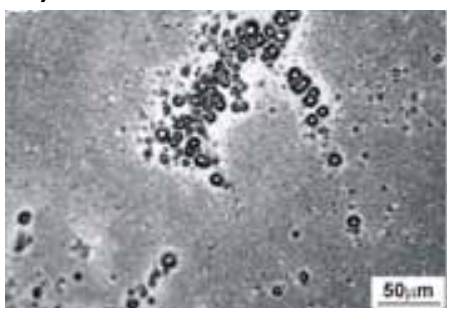

b)

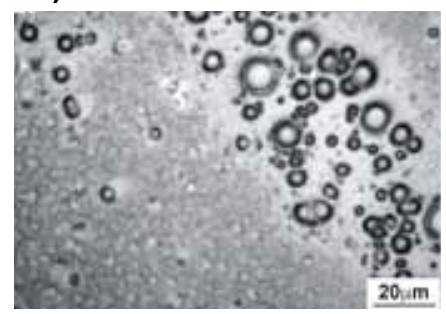

c)

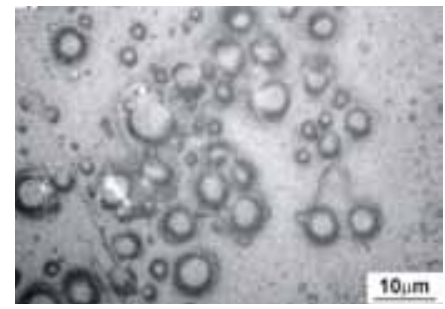

Fig. 11. Technological defect in the form of "pseudo inclusions" originating during triafol replicas preparation 


\section{Summary}

The examinations carried out show that a properly prepared replica allows reproducing accurately details of the structure from a microsection. The quality of the replica prepared depends primarily on a properly prepared microsection, mainly at the time of its etching. The best reproduction of the structure on the triafol replicas is provided by a slight overetching of the microsections. Instead, an underetching of the microsection does not allow reproducing properly its structure on the replica. The quality of a replica is substantially improved by its shading, which allows increasing the contrast of reproduced replicas. In replicas, apart from the structure reproduction, it is possible to observe defects originating in the steel microstructure (e.g. creep micropores) during the operation of equipment working e.g. long-term at elevated temperatures.

Technological defects may also originate during replica preparation, which make their subsequent evaluation difficult. Therefore the interpretation of replicas requires a lot of experience.

\section{References}

[1] S. Jana, Non-destructive In-situ Replication Metallography, Journal of Materials Processing Technology 49, pp. 85-114 (1995)

[2] L. Nilsson, R. Ohlsson, Accuracy of replica materials when measuring engineering surfaces', International Journal of Machine Tools \& Manufacture 41,pp. 2139-2145 (2001)

[3] L.G. Tham, L. Li, Y. Tsui, P.K.K. Lee, A replica method for observing microcracks on rock surfaces, International Journal of Rock Mechanics \& Mining Science 40, pp. 785-794 (2003)

[4] J.A. Newman, S.A. Willard, S.W. Smith, R.S. Piascik, Engineering Fracture Mechanics, pp. 898-910 (2009)

[5] S. Stachura, Zmiany struktury i własności mechanicznych w stalach i staliwach eksploatowanych w podwyższonych temperaturach, Energetyka 2, pp. 109 (1999)

[6] S. Stachura., M. Gwoździk, G. Golański, $5^{\text {th }}$ International Conference of PhD Students. University of Miskolc, Hungary, pp. 421-426 (2005)

[7] M. Gwoździk, S. Stachura, G. Golański, VI Międzynarodowa Konferencja Naukowa Nowe technologie i osiągnięcia w metalurgii i inżynierii materiałowej. Częstochowa, pp. 445-448 (2005)

[8] A. Barbacki, O przyczynach kruchości niskostopowych stali pracujących w podwyższonych temperaturach, Hutnik 9, pp. 306-310 (1991)

[9] A. Hernas, A. Maciejny, Żarowytrzymałe stopy metali, Ossolineum, Zakład Narodowy im. Ossolińskich, Wrocław-Warszawa-Kraków-Gdańsk-Łodź (1989)

[10] A. Barbacki, T. Kachlicki, A. Wachowiak, Inżynieria Materiałowa 4, (1987)

[11] EN 10028-2:2005, Flat products made of steel for pressure purposes - Non-alloy and Alloy steel with specified elevated temperature properties

[12] EN ISO 643:2003, Steels - Micrographic determination of the apparent grain size 